\title{
A supplement to the amphipod (Crustacea) species inventory of Helgoland (German Bight, North Sea): indication of rapid recent change
}

\author{
JAN BEERMANN AND HEINZ-DIETER FRANKE \\ Alfred Wegener Institute for Polar and Marine Research, Biologische Anstalt Helgoland, PO Box 180, 27483 Helgoland, Germany
}

\begin{abstract}
The surroundings of the rocky island of Helgoland (German Bight, south-western North Sea) are one of the best-studied sites in European seas with species occurrence data available for nearly 150 years. As the area is strongly affected by global change (e.g. increase in mean sea surface temperature at Helgoland by $1.67^{\circ} \mathrm{C}$ since 1962), ecosystem structure and function are expected to change more than those of average marine systems. The paper presents a supplement to the local amphipod species inventory ( 5 nautical miles around the island). At least seven species of this ecologically important taxon seem to have newly established themselves at Helgoland since the late 1980s: Ampelisca typica, Amphilochus brunneus, Caprella mutica, Cheirocratus assimilis, Monocorophium acherusicum, Orchestia mediterranea and Orchomenella crenata. Most of them are not only new for the Helgoland area, but also for the German Bight; and two species (Amphilochus brunneus and Orchomenella crenata) are even new to the North Sea as a whole. Out of the seven new species, one (Caprella mutica) is a neozoon from the north-western Pacific. The other six species show clear warm water affinities (oceanic-Lusitanian species) which suggest a recent range expansion in the context of climate warming. The establishment of an increasing number of species formerly probably absent from the area does not seem to be compensated by losses of species, so that local species diversity is expected to increase.
\end{abstract}

Keywords: Amphipoda, Helgoland, German Bight, North Sea, climate warming, non-indigenous species

Submitted 11 January 2011; accepted 22 February 2011

\section{INTRDDUCTION}

Amphipod crustaceans constitute a major element of marine benthic food webs, often exceeding all other taxa of macrozoobenthos in terms of numerical abundance, biomass and species diversity. Amphipods have long been recognized as sensitive indicators of water and sediment quality, and a number of species are used as biomonitors for a variety of pollutants and toxicants such as heavy metals, pesticides etc., in lakes, streams, estuaries and coastal marine areas (e.g. Reish, 1993; Thomas, 1993; Linton \& Warner, 2003; Simpson et al., 2005). Furthermore, many amphipod species exhibit a high degree of niche specificity which makes them particularly suited to document both spatial and temporal changes in environmental conditions (e.g. Marques \& Bellan-Santini, 1993; Conlan, 1994; Conradi \& López-González, 1999, 2001; Chintiroglou et al., 2004). However, despite the taxon's great ecological importance little is known on responses (e.g. geographical range shifts) of amphipods to climate warming (France, 1991; Lavaniegos \& Ohman, 1999; Mouritsen et al., 2005).

Corresponding author:

J. Beermann

Email: Jan.Beermann@awi.de
The Helgoland area, situated in the centre of the German Bight and about $60 \mathrm{~km}$ off the coast (Figure 1), is the only hard-bottom locality in the south-eastern part of the North Sea, and one of the biologically best-studied sites in European seas. Its inventory of marine species has repeatedly been studied over more than 150 years (Franke et al., 2004; Franke \& Gutow, 2004), although sporadic and opportunistic sampling dominated a systematic field monitoring over periods when the possibility of significant changes within less than the generation time of humans was not in the focus of science. Unfortunately, however, preserved material from historical surveys which would allow for a re-examination, got lost in the troubles of World War II.

Due to its land-locked, semi-enclosed nature the North Sea is experiencing a disproportionately high level of climate warming. Between 1982 and 2006 the sea surface temperature (SST) of the North Sea increased by $1.35^{\circ} \mathrm{C}$, i.e. $0.56^{\circ} \mathrm{C}$ per decade or $>_{4}$ times the global average SST decadal warming rate of $0.133^{\circ} \mathrm{C}$ (Belkin, 2009, based on UK Meteorological Office Hadley Centre SST climatology). From a daily longterm monitoring programme, SST at Helgoland (German Bight) increased by $1.67^{\circ} \mathrm{C}$ since 1962 (Wiltshire et al., 2010). Furthermore, intensive international shipping activities expose the North Sea, and particularly its coastal zones and estuaries with the large commercial ports, to a high risk of unintentional introductions of exotic species from all over the world (Reise et al., 1999; Nehring, 2006). As a marine 


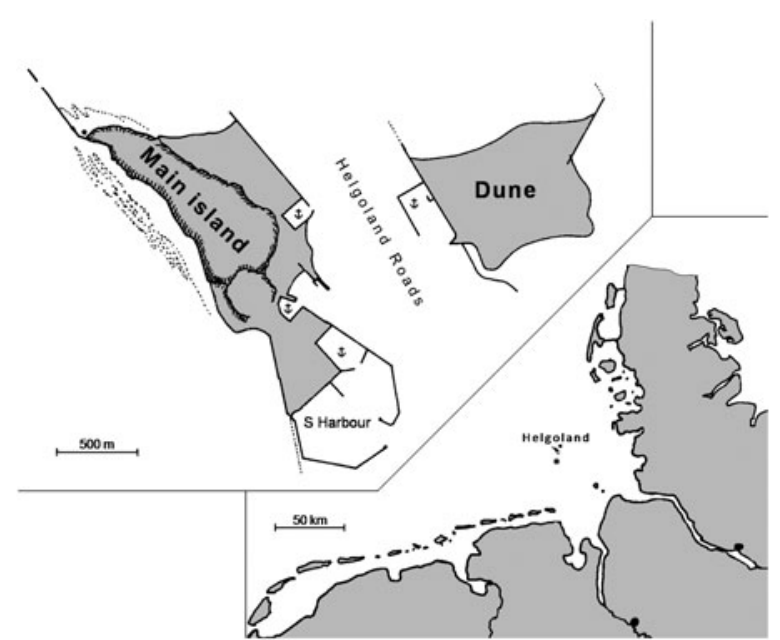

Fig. 1. Study area (island of Helgoland) and its location in the German Bight (North Sea). Asterisk indicates the position of the Tiefe Rinne south of Helgoland.

area impacted by global change much more than average, organisms and communities of the North Sea can be expected to show more rapid and stronger ecological responses than those in many other parts of the world.

Harms (1993) prepared a check list of the marine macrofauna and macroflora of the Helgoland area (up to 5 nautical miles (n.m.) around the island), compiling species occurrence data (anecdotal, observational or general in nature) collected from the 1970 s to the early 1990s. The present work is part of an assessment programme for shifts in local community composition, taking the above check list as a baseline. We report on recent $(2005-2010)$ records of species of amphipod crustaceans which are absent from the check list, i.e. which have not (or only a long time ago) been mentioned for this area before, and therefore may tentatively be regarded as new to the area. For each species we have discussed the factor(s), which might account for its recent detection in the Helgoland area, considering the following alternatives: (a) the species is not really new to the area, but has been failed to notice prior to the 1990 os due to its scarcity and, thus, low probability of detection; (b) the species is not really new to the area, but has been misclassified in the past due to taxonomic confusion; (c) the species is new to the area, and there are indications suggesting a recent expansion (or shift) of the species' geographical range from adjacent areas into the German Bight related to climate warming; and (d) the species is a neozoon, which was (either intentionally or accidentally) introduced by man across broad geographical scales to the North Sea and has established itself at Helgoland over the past two decades.

\section{MATERIALS AND METHDDS}

Most of the present work was part of an investigation carried out in 2008 and 2009 on behalf of the State Agency for Agriculture, Environment and Rural Areas (LLUR) of Schleswig-Holstein, to assess the quality of the water body at Helgoland following the demands of the European Water Framework Directive. In addition, weekly cruises with the research vessel 'Aade' were conducted during summer 2010 to collect Van Veen grab samples from different locations around Helgoland (maximum distance 3 n.m.). Ultimately, we included unpublished personal observations on Helgoland's amphipod fauna from recent years (rocky and sandy shoreline; fouling communities on navigational aids and pontoons). Voucher copies of all described species are deposited in a new Helgoland-based collection which is in the process of organization (Biologische Anstalt Helgoland, Marine Station, Alfred Wegener Institute for Polar and Marine Research) and partly in the Museum für Naturkunde, Berlin.

\section{Main sampling sites and procedures}

Sampling sites and general procedures were not different from those sampled and applied in former studies thus allowing for the detection of real changes in the local species inventory.

\section{TIEFE RINNE}

The so-called 'Tiefe Rinne' is a depression in the sea floor, situated about 1.5 n.m. south of Helgoland (Figure 1). With a depth of up to $60 \mathrm{~m}$, it is on average about $25 \mathrm{~m}$ deeper than the surrounding bottoms. It extends over $12 \mathrm{n} . \mathrm{m}$. in east-west and about 3 n.m. in north-south direction. The area is dominated by a secondary hard-bottom made up of mollusc shells, especially oyster shells from a formerly thriving but now vanished oyster bed. Sites with fine sediment occur interspersed among secondary hard bottom locations. The water body of the Tiefe Rinne shows a high and relatively constant salinity, and less seasonal temperature variation than surface waters (Caspers, 1939). This makes the area a possible stepping stone (and a refuge) for oceanic-Lusitanian species at the north-eastern border of their occurrence. Dredge samples were collected with the research vessel 'Uthörn' in September 2008 and September 2009 along five defined transects. Five subsamples ( 21 of dredged material each) per transect were taken and preserved in $4 \%$ formaldehyde in seawater. Samples were then washed and sieved using a $500 \mu \mathrm{m}$ mesh. Contained organisms were sorted out, identified to species level and counted.

\section{LAMINARIA-HOLDFASTS}

Holdfasts of the kelp Laminaria and related macroalgae are microhabitats known to harbour a broad spectrum of sessile and mobile macrofauna species (Moore, 1973; for Helgoland: Schultze et al., 1990). In July 2008 and July 2009 holdfasts of L. hyperborea (Gunnerus) Foslie were collected by SCUBA diving in two different locations (10 pieces each): boulders of the inner South Harbour in $4 \mathrm{~m}$ depth, and the northern Helgoland Roads in $6 \mathrm{~m}$ depth (Figure 1). To prevent a loss of mobile organisms as ever possible, a PVC-bag was put on each holdfast before removing it from the surface. The holdfasts were then frozen in the bags along with the complete amount of seawater and by this means preserved until further treatment.

\section{RESULTS}

Among the amphipod species demonstrated in the present investigation, 20 species are absent from the local check list (Harms, 1993) and thus might be considered as new to the 
area of study. The findings of these 'new' species, which belong to a broad spectrum of 13 different families, are given below along with specifications allowing for reliable species identifications. Furthermore, available data on the species' geographical ranges and considerations on the possible factors which may account for the species' recent occurrence in the waters at Helgoland are given.

\section{AMPELISCIDAE}

Ampelisca typica (Bate, 1856)

\section{IDENTIFICATION}

Determination using the relative lengths of the antennae has been shown to be uncertain due to high intraspecific variation within Ampelisca-species (Myers \& McGrath, 1991). Ampelisca typica can be clearly distinguished from other Ampelisca-species in the area by the presence of an angular carina on urosomite 1 (may be less pronounced in smaller specimens) in combination with a quadrate epimeral plate 3 , which shows a rounded posterodistal angle. The elongated, deeply cleft telson bears a row of dorsal setae on either site along with an apical group of setae (Figure 2; for further details: Schellenberg, 1942; Lincoln, 1979; Bellan-Santini, 1982; Dauvin \& Bellan-Santini, 1988). Body length is up to $10 \mathrm{~mm}$.

\section{RECENT RECORDS}

Dredge samples from the Tiefe Rinne yielded four specimens of A. typica in 2008, and 37 specimens in 2009. Therefore, in 2009 A. typica was the most frequently recorded Ampelisca-species next to A. diadema (Costa, 1853).

\section{REMARKS}

The distribution of A. typica ranges from south-west Norway, the British Isles, the English Channel, Bay of Biscay, Portugal to Liberia and the Mediterranean Sea (Lincoln, 1979; Bellan-Santini, 1982; Dauvin \& Bellan-Santini, 1988; Marques \& Bellan-Santini, 1993; Dauvin, 1999; Bachelet et al., 2003). According to Schellenberg (1942) this species is missing in the inner German Bight, but may occur in its peripheral parts. Considering the available occurrence data for A. typica, the species' current findings at Helgoland

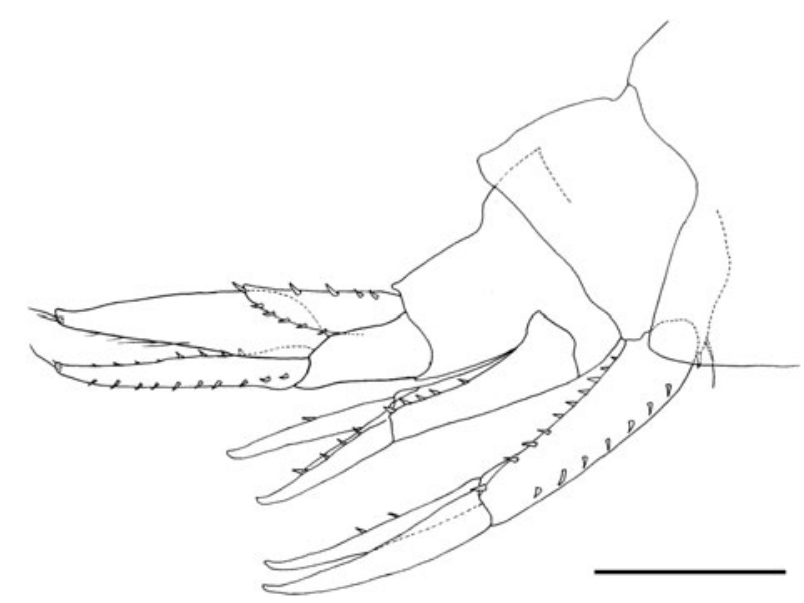

Fig. 2. Ampelisca typica (Bate, 1856). Female, $7.5 \mathrm{~mm}$ (10 September 2009). Urosome. Scale bar: $0.5 \mathrm{~mm}$.
(Tiefe Rinne) could be the result of a range expansion favoured by the recent warming trend.

\section{AMPHILOCHIDAE}

Amphilochus brunneus Della Valle, 1893

\section{IDENTIFICATION}

Similar to most other Amphilochus-species, A. brunneus shows a small body size. It is characterized by a carpal lobe on gnathopod 2 which protrudes along the posterior margin of the propodus but reaching only about $1 / 2$ to $2 / 3$ of its total length (Figure 3). The species is easy to distinguish from its sympatric congener A. neapolitanus Della Valle, 1893 where the carpal lobe on gnathopod 2 projects along the whole length of the propodal posterior margin. However, A. brunneus may be confused with A. spencebatei (Stebbing, 1876). High morphological similarity disposed Lincoln (1979) to synonymize the two species, but A. brunneus can be clearly distinguished from A. spencebatei by distinct morphological features: in A. spencebatei gnathopod 2 carpal lobes reach $3 / 4$ to $4 / 5$ of the posterior margin of the propodus. Additionally, coxa 1 of A. spencebatei is dentate on the distal margin (instead of smooth in A. brunneus) and gnathopod 1 palm is straight (convex in A. brunneus). Another species, A. borealis, was described by Enequist (1949) from the Skagerak but was discussed in the same paper to be a northern variation of A. brunneus (for further details: Enequist, 1949; Lincoln, 1979; Krapp-Schickel, 1982). Body length is up to $3 \mathrm{~mm}$.

\section{RECENT RECORDS}

One female individual was found in a dredge sample from the Tiefe Rinne in 2008. This is the first record of A. brunneus in the North Sea.

\section{REMARKS}

Earlier reports of A. brunneus are from the Mediterranean (Krapp-Schickel, 1982), Gibraltar (Conradi \& LópezGonzález, 1999) and the Irish Sea (Duhig \& Humphries, 1955; Duhig, 1960). The species shows a typical MediterraneanLusitanian distribution. Its recent record for the German Bight suggests the species to be able to profit from climate

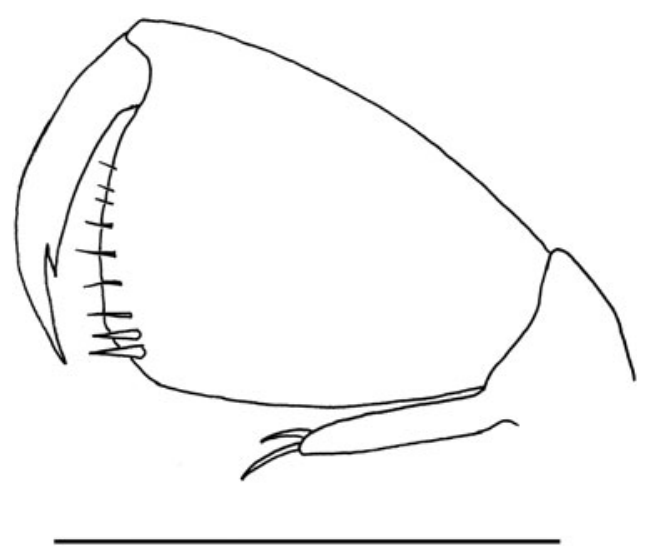

Fig. 3. Amphilochus brunneus Della Valle, 1893. Female (?), $1.5 \mathrm{~mm}$ (29 September 2008). Gnathopod 2, distal articles. Scale bar: $0.25 \mathrm{~mm}$. 
warming by expanding its range of occurrence into the North Sea.

Gitana sarsi Boeck, 1871

\section{IDENTIFICATION}

As a member of the Amphilochidae, specimens of G. sarsi are generally small in body size. The species can be distinguished from co-occurring amphilochids in the investigated area mainly by a one-articulate maxilla 1 palp and by its two simple gnathopods. Gnathopods 1 and 2 generally resemble each other but carpus of gnathopod 2 features a postero-distal lobe which is more pronounced than in gnathopod 1 . Additionally, the lobe bears a row of spines along the posterior margin and a group of spines at the distal tip (for further details: Schellenberg, 1942; Lincoln, 1979; Krapp-Schickel, 1982). Body length is up to $2 \mathrm{~mm}$.

\section{RECENT RECORDS}

In dredge samples from the Tiefe Rinne 98 (2008) and 30 specimens (2009) were found. Additionally, three individuals each were collected in the same years from Laminaria-holdfasts.

\section{REMARKS}

The species has been reported from the Norwegian coasts and western Baltic Sea to the Mediterranean Sea (Stephensen, 1938; Schellenberg, 1942; Lincoln, 1979; Krapp-Schickel, 1982; Palerud \& Vader, 1991; Dauvin, 1999; Faasse \& van Moorsel, 2000). Although the species has never been recorded before for the German Bight, we do not consider it as really new to the area, but as a species which may have been overlooked previously due to its small body size.

\section{CAPRELLIDAE}

\section{Caprella mutica Schurin, 1935}

\section{IDENTIFICATION}

Specimens of $C$. mutica are covered with conspicuous teeth on the dorsal surface of pereonites 1-7 (females) and 3-7 (males), respectively. Live specimens often feature red spots, which may disappear in preserved material. The dense setation on peronites 1 and 2, also covering gnathopod 2, leads to a 'hairy' appearance in hyperadult males. Therefore, the species is easy to distinguish from sympatric congeners in the area such as $C$. linearis (Linnaeus, 1767) (for further details: Schellenberg, 1942; McCain, 1968; Platvoet et al., 1995 as 'C. macho'; Guerra-García, 2002a; Boos, 2009; Boos et al., 2011). Body length is up to $30 \mathrm{~mm}$ (male) and $20 \mathrm{~mm}$ (female).

\section{RECENT RECORDS}

When recognized at Helgoland in 2004 for the first time (Buschbaum \& Gutow, 2005), the species had probably been present, but unidentified in the area for a number of years. The species can now be found often in huge abundances all around the island. In particular on artificial, disturbed habitats such as buoys, navigational aids and pontoons, densities can exceed 200,000 ind. $/ \mathrm{m}^{2}$ in summer. Furthermore, specimens are frequently recorded on boulders, algae and sediments all around the island.

\section{REMARKS}

The species is native to the north-east Pacific and was introduced to Pacific and Atlantic coasts of North America, to New Zealand as well as to Europe (The Netherlands, Belgium, Ireland, Scotland and Germany) (Boos et al., 2011 and references herein). In the German Bight, the species was recorded for the islands of Sylt and Helgoland (Buschbaum \& Gutow, 2005) and for the coast (Schückel et al., 2010), where it probably has established itself nearly everywhere in suitable habitats.

\section{Phtisica marina Slabber, 1769}

\section{IDENTIFICATION}

Phtisica marina is the only species of the genus known to occur in the North Sea. Its morphological characteristics are thus conspicuous among caprellid amphipods present in the investigated area. Fully developed and segmented pereopods 3 and 4 represent the most distinctive feature. The whole body is entirely smooth and slender (for further details: Schellenberg, 1942; McCain, 1968; Krapp-Schickel, 1993). Body length is up to $15 \mathrm{~mm}$.

\section{RECENT RECORDS}

The species is common on a range of substrates all around the island. From Laminaria-holdfasts 36 (2008) and 21 (2009) specimens were collected. In the Tiefe Rinne 208 and 120 individuals were recorded in 2008 and 2009, respectively. An additional specimen was found in a grab sample from the shallow waters ( $7 \mathrm{~m}$ depth) of Helgoland Roads.

\section{REMARKS}

The species has a wide occurrence. In Europe it is known from northern Norway to Gibraltar and the Mediterranean (Stephensen, 1942; Duhig, 1960; Krapp-Schickel, 1993; Dauvin, 1999; Guerra-García et al., 2002; Guerra-García \& Takeuchi, 2002; Bachelet et al., 2003). On the western Atlantic coast it occurs from North Carolina to Brazil (McCain, 1968; McCain \& Steinberg, 1970). Further records are from tropical west Africa and both the eastern and western coasts of southern Africa (Griffiths, 1973, 1974).

As the species was already frequently recorded for the North Sea (e.g. Sars, 1895; Schellenberg, 1942) and for Helgoland (Sokolowsky, 1900), it is not really new to the area, but may have been overlooked over many decades.

\section{Pseudoprotella phasma (Montagu, 1804)}

\section{IDENTIFICATION}

Currently, four species of the genus Pseudoprotella Mayer, 1890 are known to science. Amongst them, only P. phasma occurs in the North Sea (Schellenberg, 1942; Guerra-García \& Takeuchi, 2000; Guerra-García, 2002b, 2004). It is characterized by prominent projections on the dorsal surface of the head and pereonites. Pereopods 3 and 4 are reduced to small 2-articulate stubs. Thus, it makes $P$. phasma easy to distinguish from other caprellid species in the Helgoland area (for further details: Sars, 1895; Schellenberg, 1942; Krapp-Schickel, 1993; Guerra-García \& Takeuchi, 2000). Body length is up to $17 \mathrm{~mm}$. 


\section{RECENT RECORDS}

At Helgoland P. phasma was so far found only in the Tiefe Rinne: 44 specimens in 2008 and even 190 in 2009.

\section{REMARKS}

The species is known from the north-east Atlantic and adjacent seas: southern Norway, Skagerak, Kattegat, German Bight, British Isles, English Channel, Bay of Biscay, Gibraltar, Cape Verde, Mediterranean Sea, Adriatic Sea, Black and Red Sea (Schellenberg, 1942; Duhig, 1960; McCain \& Steinberg, 1970; Griffiths, 1975; Krapp-Schickel, 1993; Dauvin, 1999; Guerra-García et al., 2002; Guerra-García \& Takeuchi, 2002; Bachelet et al., 2003). For Helgoland the species was reported by Reibisch (1906). We thus consider the species as not really new to the area.

\section{CHEIROCRATIDAE}

\section{Cheirocratus assimilis (Liljeborg, 1851)}

\section{IDENTIFICATION}

Cheirocratus assimilis resembles its sympatric congener C. sundevalli (Rathke, 1843), but in the same habitat specimens of C. assimilis (recent records) were usually bigger in size. Morphological determination to species level is nearly impossible in females and small juveniles. However, mature males of $C$. assimilis can be distinguished from other Cheirocratus-species by shape and setation of the second gnathopods. The marginal palm of the propodus lacks a fringe of long setae along the margin, whereas it bears two median tubercles and is delimited by a distinct proximal tooth and a large truncated process close to the base of the dactylus (Figure 4; for further details: Lincoln, 1979; Karaman, 1982). Body length is up to $13 \mathrm{~mm}$.

\section{RECENT RECORDS}

Specimens were collected from dredge samples of the Tiefe Rinne in 2008 ( 4 individuals) and 2009 (155 individuals). This is the first published record of C. assimilis in the German Bight.

\section{REMARKS}

Cheirocratus assimilis shows a north-east Atlantic distribution occurring from south-west Norway to the Mediterranean

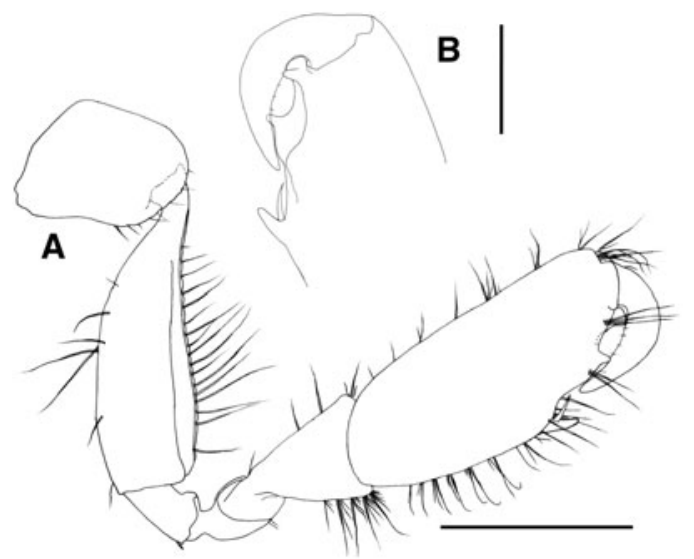

Fig. 4. Cheirocratus assimilis (Liljeborg, 1851). Male, $10.9 \mathrm{~mm}$ (10 September 2009). Gnathopod 2 (A) entire; (B) distal articles, median view. Scale bars: A, $1.0 \mathrm{~mm}$; B, $0.5 \mathrm{~mm}$.
(Stephensen, 1940; Lincoln, 1979; Karaman, 1982; Marques \& Bellan-Santini, 1993; Dauvin, 1999). For the German Bight the species is neither listed by Sokolowsky (1900, 1915) nor Schellenberg (1942), who mentions C. sundevalli to be the only Cheirocratus-species in the German Bight. The current findings at Helgoland may indicate a recent range expansion of the species related to the warming trend in the North Sea. It possibly benefits from warmer winters and the relatively stable environmental conditions of the Tiefe Rinne.

\section{COROPHIIDAE}

\section{Crassicorophium bonelli (Milne-Edwards, 1830)}

\section{IDENTIFICATION}

In older literature referred to as 'Corophium bonelli' (spelling variations: 'C. bonnellii', 'C. bonellii' and 'C. bonnelli'), this species was moved to the newly errected genus Crassicorophium by Bousfield \& Hoover (1997). Males of this common species are unknown except for a report of a single presumably male specimen (Myers et al., 1989). Hence, $C$. bonelli has for a long time been assumed to be parthenogenetic which is corroborated by observations by Moore (1981). Crassicorophium bonelli shares many characteristics with female Monocorophium insidiosum (Crawford, 1937) such as the 1-2 pairs of spines on the second antenna. However, in contrast to $M$. insidiosum, C. bonelli bears a single marginal tooth posteriorly on gnathopod 2 dactyl (instead of 2-3 teeth in $M$. insidiosum), and uropod 1 peduncle exhibits around 4 spines on the inner margin (whereas $M$. insidiosum has a single distal spine) (for further details: Schellenberg, 1942; Ingle, 1969; Bousfield, 1973; Lincoln, 1979; Bousfield \& Hoover, 1997). Body length is up to $5 \mathrm{~mm}$.

\section{RECENT RECORDS}

Specimens of $C$. bonelli were found particularly on Laminaria-holdfasts ( 28 individuals in 2008 and 25 individuals in 2009), but the species also occurred in other habitats such as the Tiefe Rinne ( 8 individuals in 2008 and 1 individual in 2009) and on rocky debris in Helgoland Roads (3 individuals).

\section{REMARKS}

The species has a wide occurrence in sub-(Ant)arctic and (anti)boreal waters: north-west Atlantic (Canada to Connecticut), north-east Atlantic (Iceland, Norway, Denmark, British Isles and Channel), north-east Pacific (Behring Sea, Alaska), south-west Atlantic (Falkland Islands), south-east Pacific (Chile) (Schellenberg, 1942; Stephensen, 1942; Bousfield, 1973; Lincoln, 1979; Bousfield \& Hoover, 1997; Dauvin, 1999). For Helgoland and the German Bight, Crassicorophium bonelli was reported (as 'Corophium bonelli') by Sokolowsky (1900), Reibisch (1906) and Schellenberg (1942). The species' absence from the check list is probably due to confusion with other co-occurring corophiid species.

\section{Monocorophium acherusicum (Costa, 1857)}

\section{IDENTIFICATION}

This species was moved from the genus 'Corophium' to a newly erected genus by Bousfield \& Hoover (1997) and is thus referred to as 'Corophium acherusicum' in older literature. In contrast to its sympatric congener $M$. insidiosum 


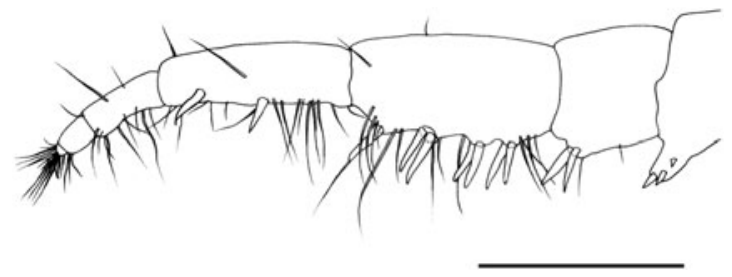

Fig. 5. Monocorophium acherusicum (Costa, 1857). Female, $4.3 \mathrm{~mm}$ (1 November 2010). Antenna 2, median view. Scale bar: $0.5 \mathrm{~mm}$.

(Crawford, 1937), females of M. acherusicum bear 3-4 pairs of spines on antenna 2 peduncle article 4 , and 2 or more spines on article 5 (Figure 5). Females of M. insidiosum have a maximum of only two pairs of spines on peduncle article 4 and a single spine on article 5. Males of M. acherusicum differ from those of $M$. insidiosum by lacking an elongated rostrum and a proximal process on the inner margin of antenna 1 peduncle article 1 , and from males of M. sextonae (Crawford, 1937) by missing spines on antenna 2 peduncle article 4. Hence, specimens of these three species, co-occurring around Helgoland, can easily be distinguished (for further details: Bousfield, 1973; Lincoln, 1979; Myers, 1982; Bousfield \& Hoover, 1997). Body length is up to $5 \mathrm{~mm}$.

\section{RECENT RECORDS}

Already in the 1990s, specimens of $M$. acherusicum were repeatedly observed on floating macroalgae off Helgoland, but not in benthic communities (Franke \& Gutow, 2004). A gravid female (3.9 mm length) was first found on Laminaria-holdfasts in 2009. In November 2010 the species occurred in large abundances $(60-70$ specimens per $100 \mathrm{~cm}^{2}$ ) on artificial panels in the South Harbour of the island.

\section{REMARKS}

The species shows a cosmopolitan distribution in warmtemperate waters of both the northern and southern hemisphere (Bousfield, 1973; Bousfield \& Hoover, 1997). In Europe the species is known from south-west Britain, the English Channel, the Bay of Biscay, Gibraltar, the Mediterranean Sea and south-west Netherlands (Wolff, 1973; Lincoln, 1979; Myers, 1982; Conradi \& López-González, 1999; Dauvin, 1999; Bachelet et al., 2003). Monocorophium acherusicum seems to be a real newcomer to the German Bight, favoured by climate warming. Except for a most recent record for the southern German Bight (as 'Corophium acherusicum') (Schückel et al., 2010), the present finding at Helgoland is the only published record of M. acherusicum for this area.

\section{CRESSIDAE}

\section{Cressa dubia (Bate 1857)}

\section{IDENTIFICATION}

Cressa dubia is the only species of the Cressidae which is known to occur in the North Sea. Although it resembles the stenothoid habitus, C. dubia can be distinguished from coexisting stenothoid species in the investigated area by some distinct features. Individuals exhibit conspicuous small dorsal teeth on pereomers $6-7$ and pleomers $1-2$. The prolonged antenna 1 is about twice as long as antenna 2. The mandible bears a well developed, long and slender palp. The distinct serrations on the posterior distal margins of coxa 2 and coxa 3 as well as the broadened basis of pereopod 5 and the coalesced telson are characteristic for the group (for further details: Schellenberg, 1942; Lincoln, 1979; Barnard \& Karaman, 1991a). Body length is up to $3 \mathrm{~mm}$.

\section{RECENT RECORDS}

In dredge samples (Tiefe Rinne) of 2009 two specimens were found, each one in a different sample. This is the first record of C. dubia for the German Bight except a single specimen which was found in the Tiefe Rinne more than one hundred years ago (Sokolowsky, 1900).

\section{REMARKS}

The north-eastern Atlantic distribution of Cressa dubia ranges from south-west Norway over the Faroes to the British Isles including the English Channel (Stephensen, 1938; Schellenberg, 1942; Duhig, 1960; Lincoln, 1979; Dauvin, 1999). This distributional pattern as well as the previous finding by Sokolowsky (1900) suggests that C. dubia is native to the Tiefe Rinne, but may have been overlooked in the past for many decades due to small body size, rarity, and a general similarity in habitus to stenothoid species.

\section{HYPERIIDAE}

Hyperia galba (Montagu, 1815)

\section{IDENTIFICATION}

Hyperia galba resembles the general hyperiid habitus with huge compound eyes covering most of the surface of the large globular head. Gnathopod 1 and the chelate gnathopod 2 are not densely covered with spines on the propodal posterior margin. Hence, specimens of $H$. galba can be distinguished from its sympatric congener $H$. medusarum (Müller, 1776) in the investigated area (for further details: Sars, 1895; Schellenberg, 1942; Stephensen, 1942; Bowman, 1973; Vinogradov et al., 1996). Body length is up to $20 \mathrm{~mm}$.

\section{RECENT RECORDS}

Hyperia galba, either free-swimming or associated with scyphomedusae, is recorded frequently from April to October in plankton samples.

\section{REMARKS}

The species can be classified as Arctic-boreal with a circumpolar distribution. On the eastern Atlantic coast it extends southward to Chesapeake Bay, in the western Atlantic it reaches the coasts of France and Spain (Sars, 1895; Stephensen, 1942; Bowman, 1973; Dauvin, 1999; Bachelet et al., 2003). In the northern Pacific, the species is known from Hokkaido and Alaska (Vinogradov et al., 1996). For Helgoland the species was recorded by Sokolowsky (1900) and Schellenberg (1942). Dittrich $(1987,1988)$ mentioned that the species, although very common around Helgoland, has been disregarded in studies on pelagic organisms in the German Bight.

The species has been a regular element of the macrofauna at Helgoland for a long time; its absence from the check list seems to be merely a mistake. 
Hyperoche medusarum (Krøyer, 1838)

\section{IDENTIFICATION}

Although resembling the basic habitus of Hyperia Latreille, 1823, Hyperoche-species feature extraordinarily formed carpochelate gnathopods 1 and 2, which allow for a safe identification. The posterior carpal processes are conspicuously laterally compressed and thus 'knife-shaped', whereas the dactylus is rather small in size. In H. medusarum the propodi of the two gnathopods do not extend beyond the tips of the carpal processes. Carpus and propodus of pereopods 3 and 5 are slightly denticulate at the posterior margin; epimeral plates 2 and 3 exhibit slightly produced, acute postero-distal corners (for further details: Sars, 1895; Schellenberg, 1942; Bowman, 1973; Bowman \& Gruner, 1973; Vinogradov et al., 1996). Body length is up to $15 \mathrm{~mm}$.

\section{RECENT RECORDS}

A single female specimen was found in a grab sample from a sandy location surrounded by rocks at $10 \mathrm{~m}$ depth.

\section{REMARKS}

This hyperiid species also shows an Arctic-boreal, circumpolar distribution. It is known from the central polar basin, the North Pacific (Bering Strait, Alaska and Kamchatka, Japan), the north-west Atlantic (Labrador and Greenland) and the north-east Atlantic (Norway, Øresund, Ireland, English Channel) (Sars, 1895 as ' $H$. krøyeri'; Schellenberg, 1942; Stephensen, 1942). Hyperoche medusarum has also been reported from the southern hemisphere (South Georgia Islands, south-west Africa and the southern tip of New Zealand (Vinogradov et al., 1996). Sokolowsky (1900) mentioned the species (as ' $H$. Kröyeri') for Helgoland. Furthermore, the species was found at Helgoland by Greve et al. (2004). The species might have been overlooked at this location over many decades due to its apparent rarity.

\section{ISCHYROCERIDAE}

\section{Ericthonius punctatus (Bate, 1857)}

\section{IDENTIFICATION}

In the common European literature Ericthonius punctatus is often referred to as E. brasiliensis (Dana, 1852) (Myers \& McGrath, 1984; Faasse \& van Moorsel, 2000). Both species exhibit a bidentate carpal process on the carpochelate male gnathopod 2. However, E. brasiliensis seems to be restricted to West Atlantic coasts and (suprisingly) the Mediterranean (Myers \& McGrath, 1984). Morphological descriptions of 'E. brasiliensis' given by Schellenberg (1942) and Lincoln (1979) for the north-east Atlantic and the North Sea clearly relate to E. punctatus. Ericthonius punctatus lacks a knob-like protuberance on the posterior margin of gnathopod 1 basis and features an oval basis on pereopods 3 and 4 which is therefore widest medially (for further details: Myers, 1982; Myers \& McGrath, 1984). Body length is up to $10 \mathrm{~mm}$.

\section{RECENT RECORDS}

High numbers of E. punctatus were found in the Tiefe Rinne in both 2008 (356 individuals) and 2009 (2342 individuals).

\section{REMARKS}

Ericthonius punctatus is known from Norway to tropical West Africa, including the British Isles, the Baltic Sea, the North Sea, the English Channel, Bay of Biscay and the Mediterranean Sea (Schellenberg, 1942; Lincoln, 1979; Myers, 1982; Myers \& McGrath, 1984; Palerud \& Vader, 1991; Dauvin, 1999; Faasse \& van Moorsel, 2000; Bachelet et al., 2003). There is no simple explanation for the absence of Ericthonius-species from the check list. The mass occurrence of Ericthonius specimens probably has developed only recently and may have been facilitated by climate warming.

Jassa herdmani (Walker, 1893)

\section{IDENTIFICATION}

Specimens of $J$. herdmani have frequently been misidentified as J. falcata (Montagu, 1808) in the past. Because of high intraspecific morphological variation in the genus Jassa, especially in male reproductive forms (Borowsky, 1985; Conlan, 1989, 1990), keys in older literature are often misleading. For instance, J. herdmani is not included in Lincoln's work (1979) on the Gammaridea of the British Isles. Fortunately, Conlan (1990) in her revision of the genus Jassa provided a reliable tool to distinguish North Atlantic Jassa-species by using characteristics not related to gender and morph. At Helgoland the two species J. herdmani and J. falcata differ from the sympatric J. marmorata Holmes, 1905 in the complete absence of setae on the anterolateral margin of the basis of gnathopod 2. To distinguish J. herdmani and J. falcata the second antenna is used. Jassa herdmani bears normal setae on antenna 2 peduncular segment 5 and the flagellum, whereas J. falcata exhibits plumose setae. Additionally, shape and segmentation of antenna 2 flagellum can be used for discrimination. Jassa falcata shows a well-developed flagellum with usually six (minimum five) segments; it is comparatively long, slender and cylindrical in form. Compared to J. falcata, antenna 2 flagellum of $J$. herdmani is stouter, laterally compressed and usually consists of only five segments (Figure 6). Furthermore, large specimens of J. falcata bear one or two spines on the inner ramus of uropod 3 in addition to the apical spine. Unfortunately, all these distinguishing features are size- and not age-related, so safe morphological determination of small specimens (although already mature) is almost impossible (Conlan, 1990, personal observation). A fourth species, J. pusilla (Sars, 1894), is also reported from

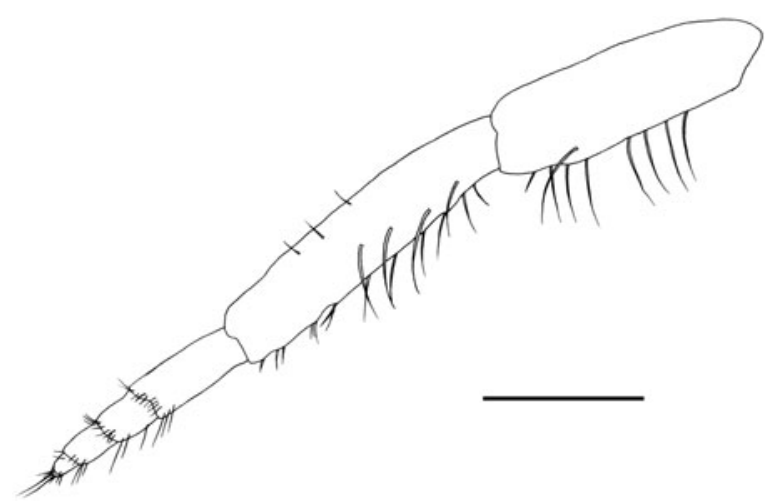

Fig. 6. Jassa herdmani (Walker, 1893). Male (major form), $12.5 \mathrm{~mm}$ (August 2008). Antenna 2. Scale bar: $1.0 \mathrm{~mm}$. 
the North Sea (Schellenberg, 1942; Conlan, 1990) but could not be confirmed for Helgoland, yet. Jassa pusilla is much smaller and slender than the other three species mentioned above. In addition, adult males of the 'major' form are characterized by a bifid tip on the propodal protuberance of gnathopod 2 (for further details: Conlan, 1990). Body length is up to $12 \mathrm{~mm}$.

\section{RECENT RECORDS}

Specimens of J. herdmani can be found throughout the year in dense populations on any kind of subtidal hard substrate. Especially on artificial substrates such as navigational aids, buoys and boulders, abundances can exceed 800.000 ind. $/ \mathrm{m}^{2}$.

\section{REMARKS}

There are no North Sea records of J. herdmani for the period before 1990. However, we were able to identify J. herdmani in old material from Helgoland labelled as ' $J$. falcata' in the collection of the Museum für Naturkunde, Berlin. In one sample, collected by the Biologische Anstalt Helgoland in 1893 (ZMB 8816), specimens of J. herdmani occurred along with specimens of J. falcata and J. marmorata. Another sample, collected by Bulemer in 1903 (ZMB 15170), consisted even exclusively of $J$. herdmani. We therefore conclude that $J$. herdmani has been present at Helgoland for a long time, but has not yet been reported before because of taxonomic confusion. Hence it is not surprising, that J. herdmani is also reported from Belgian waters and from The Netherlands (d'Udekem d'Acoz, 1993; Faasse \& van Moorsel, 2000, 2003; Zintzen et al., 2006, 2008; Havermans et al., 2007). Further reports are from south-west Norway, Denmark, the British Isles, France, Spain, Portugal and Algeria (Conlan, 1990).

\section{LYSIANASSIDAE}

\section{Orchomenella crenata Chevreux \& Fage, 1925}

\section{IDENTIFICATION}

Taxonomic status and nomenclature of the genera and subgenera of the orchomenid complex have been the subject of controversial discussions in amphipod systematics for a long time (see Barnard \& Karaman, 1991b, and references therein). Recently conducted molecular approaches for Antarctic orchomenid species additionally query previously proposed morphological divisions within the complex and indicate possible paraphyletic groupings (Havermans et al., 2010). Being synonymized with O. nana (Krøyer, 1846) by some authors, O. crenata was re-established by Kilgallen et al. (2006a), who also re-described the two species. According to these authors, the most explicit distinguishing feature is the posterior margin of epimeral plate 3 , which shows 1-3 distinct notches with inserted setae in $O$. crenata (entirely smooth in O. nana) (Figure 7; for further details: Kilgallen et al., 2006a). Body length is up to $4 \mathrm{~mm}$.

\section{RECENT RECORDS}

In the 2009 samples from the Tiefe Rinne, nine specimens were distinguished from co-occurring specimens of $O$. nana.

\section{REMARKS}

The Mediterranean-Lusitanian species has been reported from the West African coast (Sierra Leone and Senegal), the

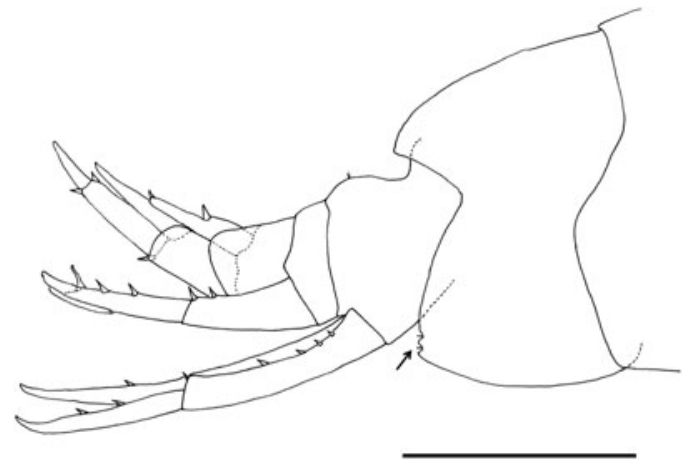

Fig. 7. Orchomenella crenata Chevreux \& Fage, 1925. Female, $4.0 \mathrm{~mm}$ (10 September 2009). Epimeron 3 and urosome. Scale bar: $0.5 \mathrm{~mm}$.

Mediterranean Sea, the English Channel and the Irish Sea (Diviacco \& Ruffo, 1989 as 'Orchomenella nana f. crenata'; Dauvin, 1999; Kilgallen et al., 2006a). Our specimens from the Helgoland Tiefe Rinne represent the first published record of O. crenata in the North Sea. The species may be considered a real newcomer to the area which is taking advantage of the recent climate warming.

Tryphosella sarsi Bonnier, 1893

\section{IDENTIFICATION}

The cosmopolitan genus Tryphosella comprises over 70 species. Their identification and taxonomic status are still a matter of debate. A systematic revision of the genus would probably lead to synonymizations and descriptions of new species. Our determinations rely on the descriptions by Lincoln (1979) and especially the recent review of Tryphosella-species of the British Isles by Kilgallen et al. (2006b). Accordingly, T. sarsi is characterized by a small dorsal hump on urosomite 1 with a small anterior depression. This feature is more pronounced in the sexually dimorphic males. Furthermore, the postero-distal corner of epimeral plate 3 is not produced and rather has a rounded quadrate shape or is even slightly acute (for further details: Lincoln, 1979; Kilgallen et al., 2006b). Body length is up to $4 \mathrm{~mm}$.

\section{RECENT RECORDS}

Tryphosella sarsi was found all around the island of Helgoland. Particularly in the Tiefe Rinne, the species was highly abundant: 34 specimens in 2008 and even 173 specimens in 2009 were gathered. Further specimens were found on Laminaria-holdfasts (2008: 8 individuals; 2009: 3 individuals) and on fine sand in $6 \mathrm{~m}$ depth at Helgoland Roads (2 individuals).

\section{REMARKS}

The species is native to north-east Atlantic coasts and adjacent seas (Norwegian Sea, Kattegat, North Sea, British Isles, western Ireland, English Channel, The Netherlands) (Sars, 1895 as 'Tryphosa nana'; Stephensen, 1935 as 'Tryphosa sarsi'; Lincoln, 1979; Dauvin, 1999; Faasse \& Stikvoort, 2002; Kilgallen et al., 2006b). For Helgoland Tryphosella sarsi was probably recorded as 'Tryphosa nana' by Sokolowsky (1900). The species' absence from the check list probably results from its confusion with other lysianassid species. 


\section{MELITIDAE}

\section{Abludomelita obtusata (Montagu, 1813)}

\section{IDENTIFICATION}

In older literature referred to as 'Melita obtusata', this species was moved to the genus Abludomelita in 1981 (Karaman, 1981). It is characterized by a dorsally smooth pleosomite 1 and a distinct median tooth on the dorso-posterior margin of pleosomite 2 which can be accompanied by two smaller lateral teeth. Large males additionally bear 1-3 dorsal teeth on pleosomite 3 (Schellenberg, 1942; Karaman, 1982). Furthermore, A. obtusata shows an entirely smooth posterior margin of epimeral plate 3. The native European Atlantic congener A. gladiosa (Bate, 1862) exhibits a toothed pleosomite 1 and a serrate posterior margin of epimeral plate 3 . It can therefore be clearly distinguished from A. obtusata (for further details: Schellenberg, 1942; Lincoln, 1979; Karaman, 1982). Body length is up to $9 \mathrm{~mm}$.

\section{RECENT RECORDS}

A single juvenile male was found in a grab sample from $35 \mathrm{~m}$ depth on fine sediment.

\section{REMARKS}

The species is known from the British Isles (Duhig, 1960; Lincoln, 1979, 'Melita'), from The Netherlands (Faasse \& van Moorsel, 2000; Faasse \& Stikvoort, 2002), English Channel (Dauvin, 1999, 'Melita'), Bay of Biscay (Bachelet et al., 2003), Portugal (Marques \& Bellan-Santini, 1993, 'Melita'), and the Mediterranean (Karaman, 1982). Findings for the German Bight were reported by Reibisch (1906), Schellenberg (1942), and (for Helgoland) by Sokolowsky (1900). Consequently, we consider A. obtusata as a species which is not really new to the Helgoland area; its apparent rarity and thus low probability of detection may account for the species' absence from the check list of 1993.

\section{PHOTIDAE}

Megamphopus cornutus Norman, 1869

\section{IDENTIFICATION}

In contrast to co-occurring Gammaropsis-species, Megamphopus-species show a small mandibular palp article 3 (smaller than article 2) and a dominant male coxa 2 (Schellenberg, 1942; Myers, 1989; Barnard \& Karaman, 1991a). Especially males of $M$. cornutus show conspicuously anteriorly prolonged coxae 1 and subquadrangular coxae 2 . Megamphopus cornutus is the only species of the genus known to occur in the North Sea (for further details: Sars, 1895; Schellenberg, 1942; Myers, 1976, 1989; Lincoln, 1979). Body length is up to $8 \mathrm{~mm}$.

\section{RECENT RECORDS}

Most specimens of $M$. cornutus were found in the Tiefe Rinne: 161 in 2008 and even 366 in 2009. Additional records were gained from grab samples at Helgoland Roads in $7 \mathrm{~m}$ water depth ( 2 individuals).

\section{REMARKS}

Records of the species have been published for Norway (Stephensen, 1942), the British Isles (Lincoln, 1979), the
North Sea (Reibisch, 1906; Schellenberg, 1942), the English Channel (Dauvin, 1999), the Bay of Biscay (Bachelet et al., 2003), Gibraltar (Conradi \& López-González, 1999) and the Mediterranean Sea (Myers, 1989). For the Helgoland Tiefe Rinne, the species was documented by Sokolowsky (1900). Although relatively abundant today, the species may have been overlooked in the area for many decades due to a possible former rarity.

\section{PONTOPOREIIDAE}

Bathyporeia sarsi Watkin, 1938

\section{IDENTIFICATION}

A detailed description of $B$. sarsi was provided by d'Udekem d'Acoz (2004). Specimens of B. sarsi are easy to identify by urosomite 1 and shape of antenna 1 peduncle article 1 (commonly known as: 'pseudorostrum'). Only two species of Bathyporeia in the North Sea bear anteriorly directed setae on urosomite 1, but lack posteriorly directed spines: $B$. sarsi and B. pilosa Lindström, 1855 (Schellenberg, 1942; Lincoln, 1979; d'Udekem d'Acoz, 2004). In contrast to B. pilosa, $B$. sarsi shows a broader, subrectangular apex of the pseudorostrum and 4-6 groups of spines on the distal margin of epimeral plate 3 in adult specimens (for further details: d'Udekem d'Acoz, 2004). Body length is up to $7 \mathrm{~mm}$.

\section{RECENT RECORDS}

High densities of $B$. sarsi were found in fine intertidal sands of the southern beach of the Dune. Abundances can exceed 500 ind. $/ \mathrm{m}^{2}$.

\section{REMARKS}

The species is known from north-east Atlantic coasts (d'Udekem d'Acoz, 2004), The Netherlands (Faasse \& Stikvoort, 2002), the British Isles (Lincoln, 1979), the English Channel (Dauvin, 1999), the Bay of Biscay (Bachelet et al., 2003) and Portugal (Marques \& Bellan-Santini, 1993). For the German Bight it was reported by Schellenberg (1942). The species is probably a regular component of the Helgoland macrofauna; its limitation to special, rarely sampled intertidal habitats may account for the species being missing from the check list.

\section{TALITRIDAE}

Orchestia mediterranea Costa, 1853

\section{IDENTIFICATION}

Adult males of $O$. mediterranea as well as those of O. gammarella (Pallas, 1763) feature conspicuously broadened carpus and merus of pereopod 7. But unlike in O. gammarella, male gnathopod 2 of O. mediterranea shows an elongated propodus with oblique palm that covers more than half the length of its posterior margin (Figure 8). Furthermore, in O. mediterranea pleopod peduncle and rami are of about equal size, whereas in O. gammarella the rami have only about half the size of the peduncle. An additional species, O. aestuarensis, is described by Wildish (1987) from the British Isles and seems to be closely related to $O$. mediterranea. The two species are distinguished inter alia by shape of pereopods 3-7 dactyls and uropod 3 spination (for further details: 


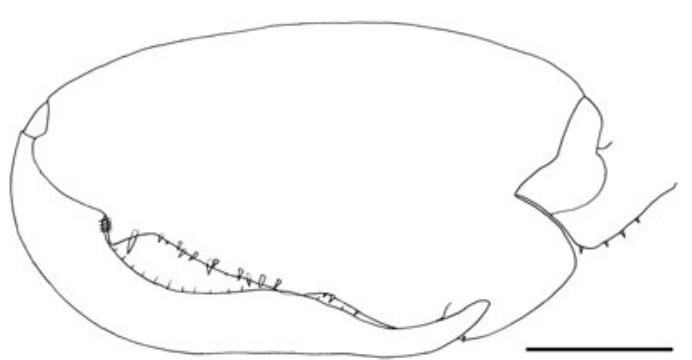

Fig. 8. Orchestia mediterranea Costa, 1853. Male, 23.5 mm (August 2009). Gnathopod 2, distal articles, median view. Scale bar: $1.0 \mathrm{~mm}$.

Schellenberg, 1942; Lincoln, 1979; Wildish, 1987; Bellan-Santini, 1993). Body length is up to $25 \mathrm{~mm}$.

\section{RECENT RECORDS}

Orchestia mediterranea is the only talitrid species recently occurring at the main island of Helgoland. It can be found all around the island in high densities under stones above high-water mark. A stone of approximately $20 \mathrm{~cm} \times 20 \mathrm{~cm}$ basal surface can cover up to 150 specimens of all size-classes.

\section{REMARKS}

The species has a typical Mediterranean-Lusitanian distribution, being known from western coasts of the British Isles (Lincoln, 1979), the English Channel (Dauvin, 1999), the Bay of Biscay (Bachelet et al., 2003) and the Mediterranean Sea (Bellan-Santini, 1993). For the North Sea, there are only two dubious findings from the German coast reported by Schellenberg (1942). The species was also recorded for Dutch estuaries (den Hartog, 1963; Platvoet \& Pinkster, 1995). There is strong evidence that O. mediterranea has only quite recently expanded its range into the German Bight. A former confusion with its congener O. gammarella can be excluded. At least at Helgoland, the formerly common and highly frequent O. gammarella (see Sokolowsky, 1900; Schellenberg, 1942) seems to have completely vanished.

\section{DISCUSSIDN}

For a first assessment of possible recent changes in the amphipod species spectrum of Helgoland, data on the local species composition for the 1970 s and 1980s (check list of Harms, 1993) were taken as a reference point. We document the occurrence of 20 species which were not recorded during the reference period and thus are absent from the above check list (Table 1). However, it would be a naive use of such occurrence data to consider all these species as real newcomers to the area. Out of the 20 'new' species, at least 11 species were not really new to the area of study as they had already been mentioned in older literature in the beginning of the 2oth Century. In a strict sense it is impossible to exclude the presence of a species in a particular area. Therefore, it must be left open, whether these species have been resident in the area continuously over the past century, overlooked over many decades, or whether they had gone locally extinct in the meantime and then successfully recolonized the area.

Among the nine species which have never been recorded before in the area, two species (Gitana sarsi and Ericthonius
Table 1. Amphipod species (with family affiliation) not included in the local check list (Harms, 1993), but recorded during a recent survey; presumed status of the species: (A) newcomer, range expansion in the context of climate warming; (B) newcomer, neozoon; (C) not really new, formerly overlooked due to scarcity; (D) not really new, formerly misclassified.

\begin{tabular}{|c|c|c|c|c|}
\hline & A & B & $\mathrm{C}$ & D \\
\hline \multicolumn{5}{|l|}{ Ampeliscidae } \\
\hline Ampelisca typica (Bate) & + & - & - & - \\
\hline \multicolumn{5}{|l|}{ Amphilochidae } \\
\hline Amphilochus brunneus Della Valle & + & - & - & - \\
\hline Gitana sarsi Boeck & - & - & + & - \\
\hline \multicolumn{5}{|l|}{ Caprellidae } \\
\hline Caprella mutica Schurin & - & + & - & - \\
\hline Phtisica marina Slabber & - & - & + & - \\
\hline Pseudoprotella phasma (Montagu) & - & - & + & - \\
\hline \multicolumn{5}{|l|}{ Cheirocratidae } \\
\hline Cheirocratus assimilis (Liljeborg) & + & - & - & - \\
\hline \multicolumn{5}{|l|}{ Corophiidae } \\
\hline Crassicorophium bonelli (Milne-Edwards) & - & - & - & + \\
\hline Monocorophium acherusicum (Costa) & + & - & - & - \\
\hline \multicolumn{5}{|l|}{ Cressidae } \\
\hline Cressa dubia (Bate) & - & - & + & - \\
\hline \multicolumn{5}{|l|}{ Hyperiidae } \\
\hline Hyperia galba (Montagu) & - & - & - & - \\
\hline Hyperoche medusarum (Krøyer) & - & - & + & - \\
\hline \multicolumn{5}{|l|}{ Ischyroceridae } \\
\hline Ericthonius punctatus (Bate) & - & - & + & - \\
\hline Jassa herdmani (Walker) & - & - & - & + \\
\hline \multicolumn{5}{|l|}{ Lysianassidae } \\
\hline Orchomenella crenata Chevreux \& Fage & + & - & - & - \\
\hline Tryphosella sarsi Bonnier & - & - & - & + \\
\hline \multicolumn{5}{|l|}{ Melitidae } \\
\hline Abludomelita obtusata (Montagu) & - & - & + & - \\
\hline \multicolumn{5}{|l|}{ Photidae } \\
\hline Megamphopus cornutus Norman & - & - & + & - \\
\hline \multicolumn{5}{|l|}{ Pontoporeiidae } \\
\hline Bathyporeia sarsi Watkin & - & - & + & - \\
\hline \multicolumn{5}{|l|}{ Talitridae } \\
\hline Orchestia mediterranea Costa & + & - & - & - \\
\hline
\end{tabular}

punctatus) show geographical patterns of distribution which suggests them to be potential residents of the Helgoland area. They may have been overlooked in the past due to rarity or difficulties in correct identification, and we thus do not consider them real newcomers.

The remaining seven species (Ampelisca typica, Amphilochus brunneus, Caprella mutica, Cheirocratus assimilis, Monocorophium acherusicum, Orchestia mediterranea and Orchomenella crenata) are probably really new not only to the Helgoland area, but (maybe with the exception of Orchestia mediterranea and Ampelisca typica) also to the German Bight. Amphilochus brunneus and Orchomenella crenata even represent new records for the North Sea as a whole. This group of species consists of one neozoon (Caprella mutica) and six species with clear warm water affinities which strongly suggests a recent range expansion in the context of climate warming.

From the western to the eastern part of the English Channel and further into the North Sea and the German Bight, there is a significant decrease in macrofauna species diversity. For instance, the local amphipod diversity diminishes from 202 species at Roscoff/western Channel to 136 species at Wimereux/eastern Channel (Dauvin, 1999); the area of Helgoland shows about 80 resident species of 
amphipods (unpublished data). Not the only, but probably the most important reason for this is a hydro-climatic gradient. Compared to other parts of the North Sea, the German Bight is strongly influenced by continental climate: in summer SST at Helgoland (highest monthly mean: $17-19^{\circ} \mathrm{C}$ in August) is significantly higher, in winter significantly lower (lowest monthly mean: $2-5^{\circ} \mathrm{C}$ in February) than in both the southern (English Channel) and northern (e.g. south Norway) parts of the North Sea where oceanic influences prevail. As species in the German Bight have to cope with both low winter and high summer temperatures, the local species inventory is rather limited and dominated by eurythermal species, while warm-stenothermal species are largely excluded from the area by cold winter temperatures, and coldstenothermal species by high summer temperatures.

Changes in geographical distribution are among the most rapid ecological responses of species to rising temperatures and have been documented for many locations and a wide array of organisms (Walther et al., 2002; Parmesan \& Yohe, 2003; Parmesan, 2006). The recent warming, particularly the trend towards milder winters, apparently relaxes the constraints which formerly prevented thermophilic (oceanicLusitanian) species from colonizing the North Sea. An increasing number of species with warm water affinities have been found to take advantage of the altered climate by extending their ranges into the North Sea (e.g. Nehring, 1998; Beare et al., 2004; Perry et al., 2005).

In contrast to terrestrial organisms (for which habitat characteristics can change drastically over short distances), marine species which live in a single, continuous medium where physical barriers to dispersal are scarce, are usually highly dispersive. This allows them to expand into adjacent areas as quickly as those become favourable to them, without any significant lag-phase. The dispersive abilities of benthic amphipods are often thought to be rather limited due to a lack of pelagic larvae. Nevertheless, many amphipods may be able to colonize rapidly adjacent areas in response to environmental changes by rafting on flotsam of biotic (macroalgae and driftwood) and abiotic (e.g. plastic litter) origin or even by freely drifting in the surface layers (Highsmith, 1985; Thiel \& Gutow, 2005; Havermans et al., 2007). For instance, prior to its recent establishment in the benthic community of Helgoland, the non-resident Monocorophium acherusicum (as 'Corophium acherusicum') was repeatedly found on floating seaweed off Helgoland in the 1990s (Franke \& Gutow, 2003), and thus may have arrived by this means.

Another phenomenon which next to a direct influence of climate warming might have favoured the appearance of new species in the area of study, are changes in ocean current dynamics and thus dispersal patterns. Advective currents can strongly affect the ranges of species with flow-induced passive dispersal (e.g. Gaylord \& Gaines, 200o). A recent increase in the influx of Atlantic waters via the English Channel to the North Sea and the German Bight (Edwards et al., 1999; Reid et al., 2001; Wiltshire et al., 2010) may accelerate the area's colonization by oceanicLusitanian species.

In the present paper, we do not explicitly deal with a possible local extinction of amphipod species in the area of study over the past decades. As 'non-detection' during a relatively shortterm investigation does not necessarily mean 'true absence', data on local species extinction are much less readily available than those on the establishment of newcomers. This can lead to an overestimation of immigration events compared to extinction processes. Nevertheless, we have no indication that amphipod species documented for the Helgoland area in the 1970 s and 1980s have gone locally extinct, with a single remarkable exception which would deserve a detailed study: Orchestia gammarella, known for mass occurrence in the first half of the 2oth Century (Sokolowsky, 1900; Schellenberg, 1942), seems to have completely vanished. Although co-occurrences of O. gammarella and O. mediterranea have been reported (e.g. for Dutch estuaries by den Hartog, 1963), the disappearance of O. gammarella at Helgoland may be the result of competitive replacement by the thermophilic newcomer O. mediterranea.

Climate change is considered a major challenge to global biodiversity, but the direction and magnitude of net change in species richness are expected to be highly non-uniform on regional and local levels (e.g. Sax \& Gaines, 2003). While increasing temperatures make the German Bight accessible to an increasing number of thermophilic species, there is little reason to assume that a comparable number of resident species will go locally extinct in the near future. The type of species which should be expected to disappear first from the area, are cold-stenotherm species. Due to the high summer temperatures in the flat German Bight, however, species with a low level of tolerance to high temperatures have rarely been native to the area in historical time. Associated with climate warming, the German Bight and to a somewhat lesser extent the North Sea as a whole will thus probably see a net-gain in the number of species. As to the hard-bottom communities at Helgoland, we probably will see them growing closer to those in south-west Britain and southern Norway with respect to species composition and diversity. Increases in local biodiversity in the context of warming have also been shown and predicted, respectively, for intertidal communities of the British Isles (Hawkins et al., 2009) and tidal flats of the Dutch Wadden Sea (Beukema \& Dekker, 2010).

Next to climate warming, the increasing introduction of non-indigenous species is widely recognized as an important component of global change and one of the major threats to global biodiversity (Vitoussek et al., 1997; Ruiz et al., 1999; Mooney \& Cleland, 2001). Out of the seven species of amphipods which have established themselves as newcomers in the Helgoland area since the early 1990s, only one is a neozoon: the invasive Caprella mutica, which is native to the north-east Pacific, but widely distributed today. The species thrives particularly in the fouling communities of artificial substrates (pontoons and buoys) where it seems to be about to displace its native congener $C$. linearis (Boos, 2009). A second (probably) non-indigenous amphipod species, Monocorophium sextonae, was already mentioned (as 'Corophium sextoni') by Harms (1993) and thus has not been considered in the present paper. Up to the 1990s, however, the species seems to have been but a rarity at Helgoland, while it now has become the absolutely dominant corophiid species in the area (unpublished data).

\section{ACKNOWLEDGEMENTS}

Part of the present work was performed on behalf of, and financed by, the State Agency for Agriculture, Nature and Rural Areas (LLUR) of Schleswig-Holstein; we thank Rolf Karez for encouragement. The study could not have been 
performed without the steady help of the crews of the research vessels 'Uthörn' and 'Aade'. Special thanks go to Captain Dieter Klings ('Aade') who substantially contributed to this work by his readiness for spontaneous operations and by his detailed knowledge of the different locations and habitats around the island of Helgoland. We are grateful to Jannica Haldin for sorting countless specimens with sedulous patience. We also would like to thank Oliver Coleman for the friendly loan of specimens from the collection of the Museum für Naturkunde (Berlin), and Traudl Krapp for a clarifying discussion on stenothoid systematics and identification. Karin Boos and Charlotte Havermans kindly contributed some of the literature.

\section{REFERENCES}

Bachelet G., Dauvin J.-C. and Sorbe J.C. (2003) An updated checklist of marine and brackish water Amphipoda (Crustacea: Peracarida) of the southern Bay of Biscay (NE Atlantic). Cahiers de Biologie Marine 44, $121-151$.

Barnard J.L. and Karaman G. (1991a) The families and genera of marine gammaridean Amphipoda (except marine gammaroids) Part 1. Records of the Australian Museum 13, 1-417.

Barnard J.L. and Karaman G. (1991b) The families and genera of marine gammaridean Amphipoda (except marine gammaroids) Part 2. Records of the Australian Museum 13, 419-866.

Beare D.J., Burns F., Greig A., Jones E.G., Peach K., Kienzle M., McKenzie E. and Reid D.G. (2004) Long-term increase in prevalence of North Sea fishes having southern biogeographic affinities. Marine Ecology Progress Series 284, 269-278.

Belkin I.M. (2009) Rapid warming of large marine ecosystems. Progress in Oceanography 81, 207-213.

Bellan-Santini D. (1982) Family Ampeliscidae. In Ruffo S. (ed.) The Amphipoda of the Mediterranean. Monaco: Mémoires de l'Institut Océanographique 13, pp. 19-69.

Bellan-Santini D. (1993) Genus Orchestia Leach, 1814. In Ruffo S. (ed.) The Amphipoda of the Mediterranean. Monaco: Mémoires de l'Institut Océanographique 13, pp. $742-753$.

Beukema J.J. and Dekker R. (2010) Increasing species richness of the macrozoobenthic fauna on tidal flats of the Wadden Sea by local range expansion and invasion of exotic species. Helgoland Marine Research, DOI 10.1007/s10152-010-0210-7.

Boos K. (2009) Mechanisms of a successful immigration from north-east Asia: population dynamics, life history traits and interspecific interactions in the caprellid amphipod Caprella mutica Schurin, 1935 (Crustacea, Amphipoda) in European coastal waters. Dissertation thesis. Freie Universität Berlin.

Boos K., Ashton G.V. and Cook E.J. (2011) The Japanese skeleton shrimp Caprella mutica (Crustacea, Amphipoda): a global invader of coastal waters. In Galil B.S., Clark P.F. and Carlton J.T. (eds) In the wrong place-alien marine crustaceans: distribution, biology and impacts. Dordrecht: Springer, pp. 129-156.

Borowsky B. (1985) Differences in reproductive behavior between two male morphs of the amphipod crustacean Jassa falcata Montagu. Physiological Zoology 58, 497-502.

Bousfield E.L. (1973) Shallow-water gammaridean Amphipoda of New England. Ithaca and London: Comstock Publishing Associates, Cornell University Press.

Bousfield E.L. and Hoover P.M. (1997) The amphipod superfamily Corophioidea on the Pacific coast of North America. Part V. Family
Corophiidae: Corophiinae, new subfamily. Systematics and distributional ecology. Amphipacifica. 2, 67-140.

Bowman T.E. (1973) Pelagic amphipods of the genus Hyperia and closely related genera (Hyperiidea: Hyperiidae). Smithsonian Contributions to Zoology 136, 1-76.

Bowman T.E. and Gruner H.-E. (1973) The families and genera of Hyperiidea (Crustacea: Amphipoda). Smithsonian Contributions to Zoology 146, 1-64.

Buschbaum C. and Gutow L. (2005) Mass occurrence of an introduced crustacean (Caprella cf. mutica) in the south-eastern North Sea. Helgoland Marine Research 59, 252-253.

Caspers H. (1939) Die Bodenfauna der Helgoländer Tiefen Rinne. Helgoländer Wissenschaftliche Meeresuntersuchungen 2, 1-112.

Chintiroglou C.-C., Antoniadou C., Baxevanis A., Damianidis P., Karalis P. and Vafidis D. (2004) Peracarida populations of hard substrate assemblages in ports of the NW Aegean Sea (eastern Mediterranean). Helgoland Marine Research 58, 54-61.

Conlan K.E. (1989) Delayed reproduction and adult dimorphism in males of the amphipod genus Jassa (Corophioidea: Ischyroceridae): an explanation for systematic confusion. Journal of Crustacean Biology 9, 601-625.

Conlan K.E. (1990) Revision of the crustacean amphipod genus Jassa Leach (Corophioidea: Ischyroceridae). Canadian Journal of Zoology 68, 2031-2075.

Conlan K.E. (1994) Amphipod crustaceans and environmental disturbance: a review. Journal of Natural History 28, 519-554.

Conradi M. and López-González P.J. (1999) The benthic Gammaridea (Crustacea, Amphipoda) fauna of Algeciras Bay (Strait of Gibraltar): distributional ecology and some biogeographical considerations. Helgoland Marine Research 53, 2-8.

Conradi M. and López-González P.J. (2001) Relationships between environmental variables and the abundance of peracarid fauna in Algeciras (southern Iberian Peninsula). Ciencias Marinas 27, 481- 500.

d'Udekem d'Acoz C. (1993) Présence et abondance de Jassa herdmani (Walker, 1893) sur la côte belge (Crustacea, Amphipoda, Ischyroceridae). De Strandvlo 13, 134-138.

d'Udekem d'Acoz C. (2004) The genus Bathyporeia Lindström, 1855, in western Europe (Crustacea: Amphipoda: Pontoporeiidae). Zoologische Verhandelingen 348, 3-162.

Dauvin J.-C. (1999) Mise à jour de la liste des espèces d'amphipodes (Crustacea: Peracarida) présents en Manche. Cahiers de Biologie Marine 40, 165-183.

Dauvin J.-C. and Bellan-Santini D. (1988) Illustrated key to Ampelisca species from the north-eastern Atlantic. Journal of the Marine Biological Association of the United Kingdom 68, 659-676.

den Hartog C. (1963) The amphipods of the deltaic region of the rivers Rhine, Meuse and Scheldt in relation to the hydrography of the area. Part II. The Talitridae. Netherlands Journal of Sea Research 2, 40-67.

Dittrich B. (1987) Postembryonic development of the parasitic amphipod Hyperia galba. Helgoländer Wissenschaftliche Meeresuntersuchungen 41, 217-232.

Dittrich B. (1988) Studies on the life cycle and reproduction of the parasitic amphipod Hyperia galba in the North Sea. Helgoländer Wissenschaftliche Meeresuntersuchungen 42, 79-98.

Diviacco G. and Ruffo S. (1989) Family Lysianassidae. In Ruffo S. (ed.) The Amphipoda of the Mediterranean. Monaco: Mémoires de l'Institut Océanographique 13, pp. 469-576.

Duhig M. (1960) The Amphipoda of Dalkey Island and its neighbouring waters. Proceedings of the Royal Irish Academy 61, 59-77. 
Duhig M. and Humphries C. (1955) Amphilochus brunneus Della Valle, an amphipod new to Britain and Ireland and notes on other amphipods not previously recorded in Irish coastal waters. Proceedings of the Royal Irish Academy 57, 123-129.

Edwards M., John A.W.G., Hunt H.G. and Lindley J.A. (1999) Exceptional influx of oceanic species into the North Sea late 1997. Journal of the Marine Biological Association of the United Kingdom 79, $737-739$.

Enequist P. (1949) Studies on the soft-bottom amphipods of the Skagerak. Zoologiska Bidrag från Uppsala 28, 269-491.

Faasse M. and Stikvoort E. (2002) Mariene en estuariene vlokreeftjes van zachte bodems in het Deltagebied (Crustacea: Gammaridea). Nederlandse Faunistische Mededelingen 17, 57-85.

Faasse M. and van Moorsel G. (2000) Niuwe en minder bekende vlokreeftjes van sublitorale harde bodems in het Deltagebied (Crustacea: Amphipoda: Gammaridea). Nederlandse Faunistische Mededelingen $11,19-44$.

Faasse M. and van Moorsel G. (2003) The North-American amphipods, Melita nitida Smith, 1873 and Incisocalliope aestuarius (Watling and Maurer, 1973) (Crustacea: Amphipoda: Gammaridea), introduced to the Western Scheldt estuary (The Netherlands). Aquatic Ecology 37, $13-22$.

France R.L. (1991) Empirical methodology for predicting changes in species range extension and richness associated with climate warming. International Journal of Biometeorology 34, 211-216.

Franke H.-D., Buchholz F. and Wiltshire K.H. (2004) Ecological longterm research at Helgoland (German Bight, North Sea): retrospect and prospect-an introduction. Helgoland Marine Research 58, 223229.

Franke H.-D. and Gutow L. (2004) Long-term changes in the macrozoobenthos around the rocky island of Helgoland (German Bight, North Sea). Helgoland Marine Research 98, 303-310.

Gaylord B. and Gaines S.D. (2000) Temperature or transport? Range limits in marine species mediated solely by flow. American Naturalist 155, 769-789.

Greve W., Reiners F., Nast J. and Hoffmann S. (2004) Helgoland Roads meso- and macrozooplankton time-series 1974 to 2004: lessons from 30 years of single spot, high frequency sampling at the only off-shore island of the North Sea. Helgoland Marine Research 58, 274-288.

Griffiths C.L. (1973) The Amphipoda of southern Africa Part 1. The Gammaridea and Caprellidea of southern Moçambique. Annals of the South African Museum 60, 265-306.

Griffiths C.L. (1974) The Amphipoda of southern Africa Part 2. The Gammaridea and Caprellidea of south west Africa south of $20^{\circ} \mathrm{S}$. Annals of the South African Museum 62, 169-208.

Griffiths C.L. (1975) The Amphipoda of southern Africa Part 5. The Gammaridea and Caprellidea of the Cape Province west of Cape Agulhas. Annals of the South African Museum, 67, 91-181.

Guerra-García J.M. (2002a) Re-descriptions of Caprella linearis (Linnaeus, 1767) and C. septentrionalis Kröyer, 1838 (Crustacea: Amphipoda: Caprellidea) from Scotland, with an ontogenetic comparison between the species and a study of the clinging behaviour. Sarsia $87,216-235$.

Guerra-García J.M. (2002b) Revision of the genus Noculacia Mayer, 1903 (Crustacea: Amphipoda: Caprellidea) with the description of two new species. Organisms Diversity and Evolution, Electronic Supplement 7 , $1-26$.

Guerra-García J.M. (2004) The Caprellidea (Crustacea, Amphipoda) from Western Australia and Nothern Territory, Australia. Hydrobiologia 522, 1-74.
Guerra-García J.M., Corzo J. and García-Gómez J.C. (2002) Clinging behaviour of the Caprellidea (Amphipoda) from the Strait of Gibraltar. Crustaceana 75, 41-50.

Guerra-García J.M. and Takeuchi I. (2000) Redescription of Pseudoprotella inermis Chevreux, 1927, a rare species of caprellidean amphipod (Crustacea) from Ceuta, North Africa. Proceedings of the Biological Society of Washington 113, 980-998.

Guerra-García J.M. and Takeuchi I. (2002) The Caprellidea (Crustacea: Amphipoda) from Ceuta, North Africa, with the description of three species of Caprella, a key to the species of Caprella, and biogeographical discussion. Journal of Natural History 36, 675-713.

Harms J. (1993) Check list of species (algae, invertebrates and vertebrates) found in the vicinity of the island of Helgoland (North Sea, German Bight) - a review of recent records. Helgoländer Wissenschaftliche Meeresuntersuchungen 47, 1-34.

Havermans C., De Broyer C., Mallefet J. and Zintzen V. (2007) Dispersal mechanisms in amphipods: a case study of Jassa herdmani (Crustacea, Amphipoda) in the North Sea. Marine Biology 153, 83-89.

Havermans C., Nagy Z.T., Sonet G., De Broyer C. and Martin P. (2010) Incongruence between molecular phylogeny and morphological classification in amphipod crustaceans: a case study of Antarctic lysianassoids. Molecular Phylogenetics and Evolution 55, 202-209.

Hawkins S.J., Sugden H.E., Mieszkowska N., Moore P.J., Poloczanska E., Leaper R., Herbert R.J.H., Genner M.J., Moschella P.S., Thompson R.C., Jenkins S.R., Southward A.J. and Burrows M.T. (2009) Consequences of climate-driven biodiversity changes for ecosystem functioning of North European rocky shores. Marine Ecology Progress Series 396, 245-259.

Highsmith R.C. (1985) Floating and algal rafting as potential dispersal mechanisms in brooding invertebrates. Marine Ecology Progress Series $25,169-179$.

Ingle R.W. (1969) The crustacean amphipod genus Corophium Latreille; a morphological and taxonomic study. Dissertation thesis. University of Reading, Reading.

Karaman G. (1981) Redescription of Melita planaterga Kunkel 1910 from Bermuda islands with revision of genera Melita Leach and Abludomelita n. gen. (Contribution to the knowledge of the Amphipoda 119). Poljoprivreda $i$ Šumarstvo 27, 29-50.

Karaman G. (1982) Family Gammaridae. In Ruffo S. (ed.) The Amphipoda of the Mediterranean. Monaco: Mémoires de l'Institut Océanographique 13 , pp. 245-364.

Kilgallen N.M., Myers A.A. and McGrath D. (2006a) Re-establishment of Orchomenella crenata (Crustacea: Amphipoda) as a distinct species, with a first record of its occurrence in the British Isles. Journal of the Marine Biological Association of the United Kingdom $86,1389-1399$

Kilgallen N.M., Myers A.A. and McGrath D. (2006b) A review of the genus Tryphosella (Crustacea: Amphipoda) from Britain and Ireland, with the description of a new species Tryphosella lowryi. Journal of the Marine Biological Association of the United Kingdom 86, $1067-1081$

Krapp-Schickel G. (1982) Family Amphilochidae. In Ruffo S. (ed.) The Amphipoda of the Mediterranean. Monaco: Mémoires de l'Institut Océanographique 13, pp. 70-93.

Krapp-Schickel G. (1993) Suborder Caprellidea. In Ruffo S. (ed.) The Amphipoda of the Mediterranean. Monaco: Mémoires de l'Institut Océanographique 13, pp. 773-813.

Lavaniegos B.E. and Ohman M.D. (1999) Hyperiid amphipods as indicators of climate change in the Californian Current. In Schram F.R. and Vaupel Klein J.C.V. (eds) Crustaceans and the biodiversity crisis. 
Proceedings of the Fourth International Crustacean Congress 1998. Leiden: Brill, pp. 489-509.

Lincoln R.J. (1979) British marine Amphipoda: Gammaridea. London: British Museum (Natural History).

Linton D.M. and Warner G.F. (2003) Biological indicators in the Caribbean coastal zone and their role in integrated coastal management. Ocean and Coastal Management 46, 261-276.

Marques J.C. and Bellan-Santini D. (1993) Biodiversity in the ecosystem of the Portuguese continental shelf: distributional ecology and the role of benthic amphipods. Marine Biology 115, 555-564.

McCain J.C. (1968) The Caprellidae (Crustacea: Amphipoda) of the western North Atlantic. United States National Museum Bulletin $278,1-147$.

McCain J.C. and Steinberg J.E. (1970) Caprellidea I. Fam. Caprellidae. Crustaceorum Catalogus 2, 1-78.

Mooney H.A. and Cleland E.E. (2001) The evolutionary impact of invasive species. Proceedings of the National Academy of Sciences of the United States of America 98, 5446-5451.

Moore P.G. (1973) The larger Crustacea associated with holdfasts of kelp (Laminaria hyperborea) in North-East Britain. Cahiers de Biologie Marine 14, 493-518.

Moore P.G. (1981) The life histories of the amphipods Lembos websteri Bate and Corophium bonnellii Milne Edwards in kelp holdfasts. Journal of Experimental Marine Biology and Ecology 49, 1-50.

Mouritsen K.N., Tompkins D.M. and Poulin R. (2005) Climate warming may cause a parasite-induced collapse in coastal amphipod populations. Oecologia 146, 476-483.

Myers A.A. (1976) The genera Megamphopus Norman and Microprotopus Norman (Amphipoda-Gammaridea) in the Mediterranean. Bulletin du Muséum National d'Histoire Naturelle, ze série 357, 121-132.

Myers A.A. (1982) Family Corophiidae. In Ruffo S. (ed.) The Amphipoda of the Mediterranean. Monaco: Mémoires de l'Institut Océanographique 13, pp. 185-208.

Myers A.A. (1989) Family Isaeidae. In Ruffo S. (ed.) The Amphipoda of the Mediterranean. Monaco: Mémoires de l'Institut Océanographique 13, pp. $395-426$.

Myers A.A. and McGrath D. (1984) A Revision of the North-East Atlantic species of Ericthonius (Crustacea: Amphipoda). Journal of the Marine Biological Association of the United Kingdom 64, 379-400.

Myers A.A. and McGrath D. (1991) The Ampelisca diadema group of species (Amphipoda: Gammaridea) in British and Irish waters. Journal of the Marine Biological Association of the United Kingdom $71,265-279$.

Myers A.A., McGrath D. and Cunningham P. (1989) A presumed male of the parthenogenetic amphipod Corophium bonnelli (Milne-Edwards). Journal of the Marine Biological Association of the United Kingdom 69, 319-321.

Nehring S. (1998) Establishment of thermophilic phytoplankton species in the North Sea: biological indicators of climate changes? ICES Journal of Marine Science 55, 818-823.

Nehring S. (2006) Four arguments why so many alien species settle into estuaries, with special reference to the German River Elbe. Helgoland Marine Research 60, 127-134.

Palerud R. and Vader W. (1991) Marine Amphipoda Gammaridea in North-East Atlantic and Norwegian Arctic. Tromura 68, 1- 101.

Parmesan C. (2006) Ecological and evolutionary responses to recent climate change. Annual Review of Ecology, Evolution and Systematics $37,637-669$.
Parmesan C. and Yohe G. (2003) A globally coherent fingerprint of climate change impacts across natural systems. Nature 421, 37-42.

Perry A.L., Low P.J., Ellis J.R. and Reynolds J.D. (2005) Climate change and distribution shifts in marine fishes. Science 308, 1912-1915.

Platvoet D., de Bruyne R.H. and Gmelig Meyling A.W. (1995) Description of a new Caprella-species from the Netherlands: Caprella macho nov. spec. (Crustacea, Amphipoda, Caprellidae). Bulletin Zoölogisch Museum, Universiteit van Amsterdam 15, 1-4.

Platvoet D. and Pinkster S. (1995) Changes in the amphipod fauna (Crustacea) of the Rhine, Meuse and Scheldt etuary due to the Delta Plan' coastal engineering works. Netherlands Journal of Aquatic Ecology 29, 5-30.

Reibisch J. (1906) Faunistisch-biologische Untersuchungen über Amphipoden der Nordsee. 2. Teil. Wissenschaftliche Meeresuntersuchungen Abteilung Kiel 9, 185-236.

Reid P.C., de Fatima Borges M. and Svendsen E. (2001) A regime shift in the North Sea circa 1988 linked to changes in the North Sea horse mackerel fishery. Fisheries Research 50, 163-172.

Reise K., Gollasch S. and Wolff W.J. (1999) Introduced marine species to the North Sea coasts. Helgoländer Wissenschaftliche Meeresuntersuchungen 52, 219-234.

Reish D.J. (1993) Effects of metals and organic compounds on surviva and bioaccumulation in two species of marine gammaridean amphipod, together with a summary of toxicological research in this group. Journal of Natural History 27, 781-794.

Ruiz G.M., Fofonoff P., Hines A.H. and Grosholz E.D. (1999) Non-indigenous species as stressors in estuarine and marine communities: assessing invasion impacts and interactions. Limnology and Oceanography 44, 950-972.

Sars G.O. (1895) An account of the Crustacea of Norway with short descriptions and figures of all the species. Volume 1: Amphipoda. Christiania, Copenhagen: Alb. Cammermeyers Forlag.

Sax D.F. and Gaines S.D. (2003) Species diversity: from global decreases to local increases. Trends in Ecology and Evolution 18, 561-566.

Schellenberg A. (1942) Flohkrebse oder Amphipoda. Jena: Gustav Fischer Verlag.

Schückel U., Schückel S., Beck M. and Liebezeit G. (2010) New range expansion of Caprella mutica Schurin, 1935 (Malacostraca: Caprellidae) to the German coast, North Sea. Aquatic Invasions 5, $85-89$.

Schultze K., Janke K. and Krüß A. (1990) The macrofauna and macroflora associated with Laminaria digitata and L. hyperborea at the island of Helgoland (German Bight, North Sea). Helgoländer Wissenschaftliche Meeresuntersuchungen 44, 39-51.

Simpson S.L., Batley G.E., Chariton A.A., Stauber J.L., King C.K., Chapman J.C., Hyne R.V., Gale S.A., Roach A.C. and Maher W.A. (2005) Handbook for sediment quality assessment. Bangor (NSW): CSIRO

Sokolowsky A. (1900) Die Amphipoden Helgolands. Wissenschaftliche Meeresuntersuchungen (Abteilung Helgoland) 4, 143-166.

Sokolowsky A. (1915) Nachträge zur Amphipodenfauna Helgolands. Wissenschaftliche Meeresuntersuchungen (Abteilung Helgoland) 16, $1-6$.

Stephensen K. (1935) The Amphipoda of North Norway and Spitsbergen with adjacent waters Part 1. Tromsø Museums Skrifter 3, 1-140.

Stephensen K. (1938) The Amphipoda of North Norway and Spitsbergen with adjacent waters Part 2. Tromsø Museums Skrifter 3, 141-278.

Stephensen K. (1940) The Amphipoda of North Norway and Spitsbergen with adjacent waters Part 3. Tromsø Museums Skrifter 3, 279-362. 
Stephensen K. (1942) The Amphipoda of North Norway and Spitsbergen with adjacent waters Part 4. Tromsø Museums Skrifter 3, 363-526.

Thiel M. and Gutow L. (2005) The ecology of rafting in the marine environment. II. The rafting organisms and community. Oceanography and Marine Biology: an Annual Review 43, 279-418.

Thomas J.D. (1993) Biological monitoring and tropical biodiversity in marine environments: a critique with recommendations, and comments on the use of amphipods as bioindicators. Journal of Natural History 27, 795-806.

Vinogradov M.E., Volkov A.F. and Semenova T.N. (1996) Hyperiid amphipods (Amphipoda, Hyperiidea) of the world oceans. Lebanon: Science Publishers Inc.

Vitoussek P.M., d'Antonio C.M., Loope L.L., Rejmanek M. and Westbrooks R. (1997) Introduced species: a significant component of human-caused global change. New Zealand Journal of Ecology 21, $1-16$.

Walther G.-R., Post E., Convey P., Menzel A., Parmesan C., Beebee T.J.C., Fromentin J.-M., Hoegh-Guldberg O. and Bairlein F. (2002) Ecological responses to recent climate change. Nature 416, $389-395$.

Wildish D.J. (1987) Estuarine species of Orchestia (Crustacea: Amphipoda: Talitroidea) from Britain. Journal of the Marine Biological Association of the United Kingdom 67, 571-583.
Wiltshire K.H., Kraberg A., Bartsch I., Boersma M., Franke H.-D., Freund J., Gebühr C., Gerdts G., Stockmann K. and Wichels A. (2010) Helgoland Roads, North Sea: 45 years of change. Estuaries and Coasts 33, 295-310.

Wolff W.J. (1973) The estuary as a habitat-an analysis of data on the soft-bottom macrofauna of the estuarine area of the rivers Rhine, Meuse and Scheldt. Zoologische Verhandelingen 126, 1-242.

Zintzen V., Massin C., Norro A. and Mallefet J. (2006) Epifaunal inventory of two shipwrecks from the Belgian Continental Shelf. Hydrobiologia 555, 207-219.

and

Zintzen V., Norro A., Massin C. and Mallefet J. (2008) Temproral variation of Tubularia indivisa (Cnidaria, Tubulariidae) and associated epizoites on artificial habitat communities in the North Sea. Marine Biology 153, 405-420.

\section{Correspondence should be addressed to:}

J. Beermann

Alfred Wegener Institute for Polar and Marine Research Biologische Anstalt Helgoland

PO Box 180, 27483

Helgoland, Germany

email: Jan.Beermann@awi.de 